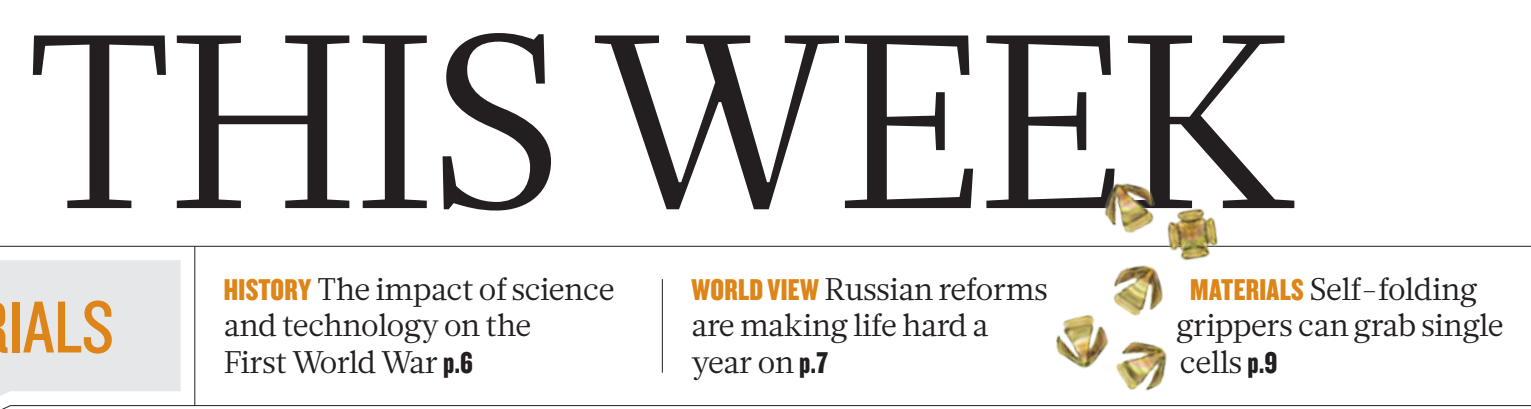

EDITORIALS and technology on the First World War p.6 are making life hard a year on $\mathbf{p . 7}$

\title{
Academic freedom under threat
}

\author{
The human rights of academics in Egypt are being eroded by the military regime that has taken \\ control of the country. The Arab Spring is on hold.
}

$\mathrm{E}$ mad Shahin, a political-sciences scholar, has been in exile since January, when the Egyptian authorities issued a warrant for his arrest. He was at a conference in the United States at the time and, fearing that he will not get a fair trial in Egypt, he has not been home since. The charges against him, which Shahin declares are "ludicrous", include espionage and being a leading member of the Muslim Brotherhood, the party of former president Mohammed Morsi, who was ousted in a military coup last July. The new regime has declared the Muslim Brotherhood a terrorist organization.

It is true that Shahin has been vocally critical of the new regime. As an internationally renowned professor of public policy and administration at the American University in Cairo, he was also critical of the repressive 30-year dictatorship of Hosni Mubarak, and occasionally criticized the Morsi regime that was ushered in after Mubarak was deposed in 2011 following a popular uprising, part of the Arab Spring.

The International Human Rights Network of Academies and Scholarly Societies, based in Washington DC, has actively taken up Shahin's case, and says that it will continue to defend his right to freedom of expression until all charges are dropped. Sadly, Shahin is only one of many Egyptian academics whose human rights seem to be under threat. The network has also expressed concern that, among 41,000 prisoners arrested since the coup, around 1,000 are engineers, physicians and scientists.

In April, a group of Egyptian scholars published a report on the academic victims of the unrest that followed the military coup, documenting by name and affiliation those who had been arrested or killed by the Egyptian authorities. The tally includes 1,347 student arrests and 176 student deaths. Sixteen of the deaths took place during police raids on campus. Seven faculty members have been killed, 160 placed under arrest, 20 put on parole and 25 are on the run.

What frustrated the hopes of the Egyptian Arab Spring? Morsi, an Islamist - who happens to hold a PhD in materials science - only narrowly beat his secular opponents to become the country's first democratically elected president. But moves he made to empower the Muslim Brotherhood alienated many. He proved unable to control the economy, and the country descended once again into political chaos.

Impatient for change after the revolution, in September 2011 thousands of university faculty staff from around the country demonstrated in Cairo, demanding that university leaders - all appointed directly by Mubarak - be replaced. A system allowing faculty members to elect their own rectors and deans was introduced. The protesters had also called for police to be banned from campuses unless explicitly invited by university administrations - a reaction against the oversight of campuses by state security guards during Mubarak's rule.

The new era has reversed both of these reforms. Almost immediately, police moved onto campuses to disrupt frequent demonstrations there against the regime, many organized by Islamist sympathizers angry at Morsi's removal, and many of which interrupted teaching activities. As

the new statistics show, the clashes too often ended in violence.

And last week, Morsi's successor, Abdel Fattah al-Sisi, issued a presidential decree that puts the appointment of university leaders once more under his control, a move that is widely believed will allow the regime to oust any supporters of the Muslim Brotherhood who have been elected to the posts.

Democracy cannot be built in a day. Egyptian universities have on occasion been rather naive in their response to their new freedoms. The

"Egyptian police have been unacceptably brutal in dealing with some protesters." faculty election is better than crude political appointment.

Few campuses in the world exclude police. Greece, for example, responding to police violence against protesting students during its own previous military dictatorship, banned police entry to its universities in 1982. But as its democracy matured, its universities became more worried about the organized crime that had moved into the safe haven of the campuses - so the law was reversed in 2011. Egyptian police have been unacceptably brutal in dealing with some protesters.

Right now, academic freedom in Egypt looks to be in great jeopardy. Academics outside the country can only look on in despair and hope that the strategy of the human-rights network that represents them can at least win its battle for fair treatment of the academics detained for expressing their opinions.

\section{STAP retracted}

\section{Two retractions highlight long-standing issues of trust and sloppiness that must be addressed.}

$\mathrm{T}$ This week, Nature publishes retractions of two high-profile papers that claimed a major advance in the field of stem cells (see page 112). Between them, the two papers seemed to demonstrate that a physical perturbation could do what had previously been achieved only by genetic manipulation: transform adult cells into pluripotent stem cells able to differentiate into almost any other cell type. The acronym STAP (stimulus-triggered acquisition of pluripotency) became instantly famous.

Soon after the papers were published on 30 January, cracks appeared 